\title{
The Relationship Between Information \& Communication Technology and Foreign Direct Investment Inflow to Africa
}

\author{
Abdisalan Salad Warsame ${ }^{1}$ \\ ${ }^{1}$ Faculty of Economics, Somali National University, Mogadishu, Somalia \\ Correspondence: Abdisalan Salad Warsame, Faculty of Economics, Somali National University, Mogadishu, \\ Somalia. E-mail: awarsame@ snu.edu.so
}

Received: February 21, 2021

Accepted: March 15, 2021

Online Published: April 10, 2021

doi:10.5539/ijef.v13n5p22

URL: https://doi.org/10.5539/ijef.v13n5p22

\begin{abstract}
This paper examined the relationship between the increasing Information \& Communication Technology (ICT) infrastructure in Africa and foreign direct investment inflow to Africa using panel data sourced from ITU and WDI over 17 years (1998-2014). The paper applies both the fixed-effect and difference-in-differences models. The results indicate that there is a positive correlation between FDI inflow and ICT level in the host country. The surge in ICT infrastructure in 2009 has substantially increased the FDI inflow to Africa. This increase in FDI inflow was more in the countries that have access to the sea than the countries that have no access to the sea. In other words, the average scale change in FDI inflow to the countries with no access to the sea is smaller than the countries with the coastline.
\end{abstract}

Keywords: FDI, ICT infrastructure, internet, Mobile Phone, PC

\section{Introduction}

In Africa, Information Communication and Technology (ICT) infrastructures have been in surge and expected to have different levels of development impacts on the countries in the continent. This paper focused on how ICT"the greatest invention of humans" (The Economist 2012) - makes Africa attractive to MNEs? In Africa, ICT infrastructures have been in a surge since earlier 2000s, which helped citizens to have better access to the internet and increased the number of mobile phone subscribers substantially in making Africa attractive as a whole. It is believed that the greater the ICT infrastructure existence, the cheaper and easier access to ICT. The ICT itself promotes the adaptation of ICT technologies that create an attractive Africa to international investors. To verify that, the study analyzes the relationship between FDI inflow and ICT infrastructures in Africa using macro-level data spanning 17 years (1998-2014) in 53 African countries using the fixed-effect method.

It also addressed some potential endogeneity that may originate from the relationship between FDI and ICT, employing the quasi-experimental method. Although the submarine's internet cables belong to African companies while major FDI inflows to Africa come from outside of Africa, some amount of the investments in ICT infrastructures might be part of FDI inflow to Africa that could lead to endogeneity problem. To deal with this problem, the researcher grouped African countries: landlocked countries as control and countries with sea access as a treatment group using natural experiment techniques.

In this study, the researcher doesn't care much about whether landlocked countries enjoy fast speed internet or suffer from poor connectivity internet capacity due to distance, but obviously, they never have a chance to get direct submarine internet cable because they are landlocked. The researcher does this because the focal point of interest is not about the internet speed but the country's accessibility to the coastline, which affects economic development and overall country's attractiveness to FDI inflow, ceteris paribus. So, the study compares the average change of FDI inflow in landlocked countries with the average change of those countries with sea access after and before 2009 (policy year). Talking about a landlocked country, the first things that come to the mind are the transportation of goods and fishing activities, this study shows that the coastline is important to a country's development beyond those activities.

Then, robust results show that Information \& Communication Technology has a positive and significant relationship with FDI inflow to Africa. The study indicates that an increase in ICT infrastructure increases the FDI inflow to Africa. After 2009, the increase in ICT infrastructures has substantially increased the FDI inflow to 
Africa, particularly in the countries with coastline than in the landlocked ones. In other words, the average changes in the FDI inflow to countries with the coastline in Africa, after 2009, are greater than that of the landlocked countries. This implies fiber optic submarine cables contribute more economic advantages to countries that have access to sea compared to landlocked countries, through attracting more FDI inflow. The paper contributes that ICT attracts more FDI inflows for the countries that have access to sea shores than landlocked countries; ceteris paribus. The countries alongside the sea receive first-hand internet undersea cables while landlocked countries rely on the transferred internet, which might be not the same in terms of capacity and costs.

\subsection{Literature Review}

The role of Information and Communication Technology (ICT) in global business activities has become essential because ICT is widely used within all types of industries. The world economy has been moving from a primary sector-based economy to a knowledge-based economy where ICT is important for economic growth through attracting Foreign Direct Investment (FDI) inflow, enhancing a country's productivity, and promoting the global business competition. In both the developed and developing world, ICT becomes a fundamental factor that needs to be taken into consideration when examining what factor determines FDI inflow and economic growth. ICT makes the economy more efficient and effective in facilitating the world business activities via promoting R\&D, reducing communication costs, easing information accessibility, and quickens business transactions. This chapter investigates the relationship between the increasing ICT in Africa and FDI inflow to Africa over the period of 17 years (1998-2014).

The current literature about the role of Information and Communication Technology (ICT) in FDI inflow has found similar findings. According to Addison and Heshmati (2003), the development in ICT has positive effects on FDI inflows to developing economies. ICT has a significant and positive effect on FDI inflow (Romansch, 2016; Fakher, 2016). According to an empirical study on sixty low-income and lower-middle-income countries, ICT can effectively attract FDI inflow, Mottaleb (2007). ICT is essential to growth through FDI. ICT enhances a country's productive capacity in all industries, and at the same time, it integrates a country with the global economy while promoting competitiveness (Hassan, 2003; Bala et al., 2006). An increase in ICT sector investments leads to a surge in FDI inflow to developing economies (Gholami et al., 2005). Studies in 95 and 8 MENA countries found growth and inward FDI are associated with ICT and globalization (Hassan, 2003). Another study found a significant relationship between the FDI inflows and the level of ICT, which means that the multinational enterprises consider ICT level as a key factor that determines FDI site choice (Veljanoska et al., 2013).

The "ICT technologies are not randomly allocated, but introduced where economic benefits are expected" (Hjort \& Poulsen, 2019). Besides information and communication technology attracting direct foreign investment, it also impacts the economy in many ways including promoting entrepreneurship, financial markets, innovation, and aids education. The study found that increasing mobile ownership to 10 cell phones per 100 individuals can increase income per capita around $0.8-1.2$ percent in developing economies and by 0.6 percent in developed economies (Waverman et al., 2005). A global level study about determinants of mobile phone ownership revealed personal income as key determinants (Zhang, 2017). In Brazil, gender, income, and age are identified as major determinants (Nishijima et al., 2017) as well as in India (Gupta \& Jain, 2015). Although many researchers show a positive relationship between ICT and FDI inflow, these findings may not necessarily be representative in the African context. Thus, this particular chapter focuses on how ICT makes Africa attractive to multinational enterprises.

FDI studies on Sub-Sahara countries found that trade openness, human capital, natural resource endowment, and market size are the determinants (Rjoub et al., 2017). Empirical studies found that FDI inflow is attracted by the large market size (Blomstrom \& Lipsey, 1991; Alan \& Estrin, 2004; Na \& Lightfoot, 2006; Lee et al., 2008; Kang \& Jiang, 2010). The large market size of the host country enables MNEs to achieve a cost-effectiveness strategy through an economy of scales of domestic productions (Markusen \& Venables, 1999; Braunerhjelm \& Svenson, 1996). Chinese Firms go out of China for market-seeking after facing cut-throat competition pressure at home (Deng 2004; Buckley et al., 2007-8). MNEs seek cheaper factors of production (e.g., raw materials, labor, and distribution strategy), Dunning (1973). Firm location choice in cities shows that production inputs influence the firm's location choice in China and India (Sridhar \& Wan, 2010). Chinese FDI has a positive relation to the economic growth of destination countries (Kang \& Jiang, 2010). FDI inflow to Sub-Saharan African countries is market seeking, not resource seeking (Okafora, Piesseb, \& Webster, 2015). The most influential factors of FDI attraction in SSA are political-economic stability and factor of production (Bartels, et al., 2014). 
Chinese MNEs invest in locations with good institutional standards, developing with more natural resource endowment as well as high return and cheaper factors of production (Yang et al., 2018). FDI flow into locations with non-renewable natural resources (Faeth, 2009; Chanegriha et al., 2016; Teixeira, Forte, \& Assuncao, 2017): Natural resource endowment attributes, most specifically, non-renewable natural resources and human capital (Asiedu, 2006; Cleeve, 2008). Location-specific attributes that drive FDI inflow include skilled workforces and good infrastructures (Na \& Lightfoot, 2006; Marti, Alguacil, \& Orts, 2015; Blanc-Brude et al., 2017; Du, Lu, \& Tao, 2007): Location Attribute factors, the agglomeration has positively correlated with FDI (Coughlin et al., 1991, Wheeler \& Moody, 1992; Braunerhjelm \& Svensson, 1996; Belkhodja1, 2016): and Intellectual property protection as major location determinants (Wu, 2000; Javorcik, 2004; Belkhodja1, 2016): agglomeration has a stronger impact on high-tech economies than in low-tech countries (Yao et al., 2016).

\subsection{Information and Communication Technology (ICT) in Africa}

Earlier in 2000, the international Internet bandwidth in Africa was less than the country of Luxembourg (ITU, 2000). By 2013, more than half of urban adults have Internet-capable devices (McKinsey Global Institute, 2013). Around 13 percent of all African population use the Internet, relative to 36 percent globally (Internet Society, 2013). By 2020, the mobile broadband connections in the sub-Sahara region will rise to half a billion, twice more than the numbers in 2016 representing two-third of total connection in the region (GSMA, 2017). In Africa as a whole, 3G Mobile broadband has mainly dominates the network but there is about 100 4G network in 39 countries. By 2002, a cell phone ownership in Uganda, Ghana, Tanzania, and Kenya was approximately one-in-ten while today cellphone ownerships are as common as in the United States (Pew Research Center, 2015). In sub-Saharan Africa, people use cell phone more than they use electricity (The Economist, 2017). By 2016, in Sub-Sahara Africa, there were about 420 million mobile phone subscribers while 731 million SIM connections existed in the region. At the end of 2020, cell phone subscribers will reach about one billion. In the region, more than 200 million people use smartphone connection accounting for one-fourth of mobile phone connection (GSMA, 2017). In 2017, 747 million people had SIM connections in the region (DZNet, 2018).

The main driving factors of an increasing ICT infrastructure in Africa include mobile banking, education and greater ICT itself leads to more usage of ICT technologies in narrowing the technology disparity among the population (Forenbacher et al., 2019). The internet blackout costs Somalia approximately more than $\$ 10$ million loss per day after a vessel cut undersea fiber optic cables (African news, 2017). This implies that, ICT is the backbone of business activities and communication in the region. The Organization for Economic Cooperation and Development (OECD, 2018), found ICT disparities among individuals, households, and locations are due to their differences in socioeconomic factors in terms of ICT accessibility and internet application for various activities. The ownership of personal computer indicates economic development in a particular area or country because Personal Computer (PC) is a luxury good and only for those who have disposable income. PC incurs costs including electricity, internet packages or bundles, and maintenance. Besides economic development indicators, the use of cell phones, computers, and the internet also indicate human literacy because these tools are for those who can read and write.

The ICT infrastructure in Africa has started dramatically developing from early 2000, specifically after submarines internet cables began arriving in Africa. these internet cables have increased the internet capacity and availability, promoting mobile phone ownership beyond our imagination. But yet, there is a gap in our understanding of how the increasing ICT infrastructure in Africa impacts FDI Inflow to the continent. Therefore, this chapter focuses on investigating how ICT- "the greatest invention of humans" (The Economist 2012) - makes Africa attractive to MNEs? The researcher believes that the greater ICT infrastructure existence, the cheaper and easier access to ICT. The ICT itself promotes the adaptation of ICT technologies that create an attractive Africa to investors. The study indicated that an increase in ICT infrastructure increases the FDI inflow to Africa. After 2009, the increase in ICT has substantially increased the FDI inflow to Africa, particularly in the countries with coastline than landlocked nations. In other words, average changes in FDI inflow to countries with the coastline in Africa after 2009 are greater than that of the landlocked countries. This implies, Fiber Optic submarine cables contribute more economic advantages to countries that have access to sea compared to the landlocked, through attracting more FDI inflow.

As figure 1 presents, FDI inflow and Internet users in Africa grow together smoothly over time. Internet users surpassed the FDI inflow in 2011 showing peaking patterns while FDI also kept increasing at a lower span than internet users. This is an indication of many important factors including the development of human literacy, income, and technology. Literacy is a minimum requirement for technology application. More than other variables, mobile phone ownership has dramatically increased over time (see figure 2). Recently, mobile phones have become multipurpose and multifunctional tools for mobile banking, internet, notebook, calling and fashion. This importance of mobile phones makes them part of our daily lives causing a gradual decrease in a personal 
computer's usage, see figure 2. Personal computer ownerships fluctuate up and down over time while slightly keeping the flat shape. FDI inflow and Internet users are increasingly moving together over time.

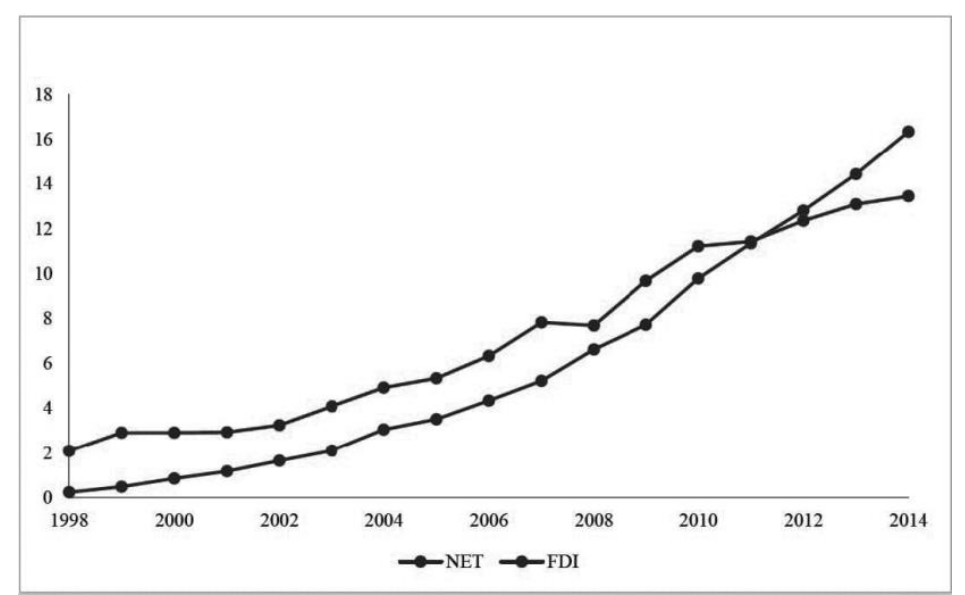

Figure 1. Mean of internet users and FDI inflow (1998-2014)

Note. Net=internet users. FDI=FDI Inflow to Africa.

Source: author's calculation.

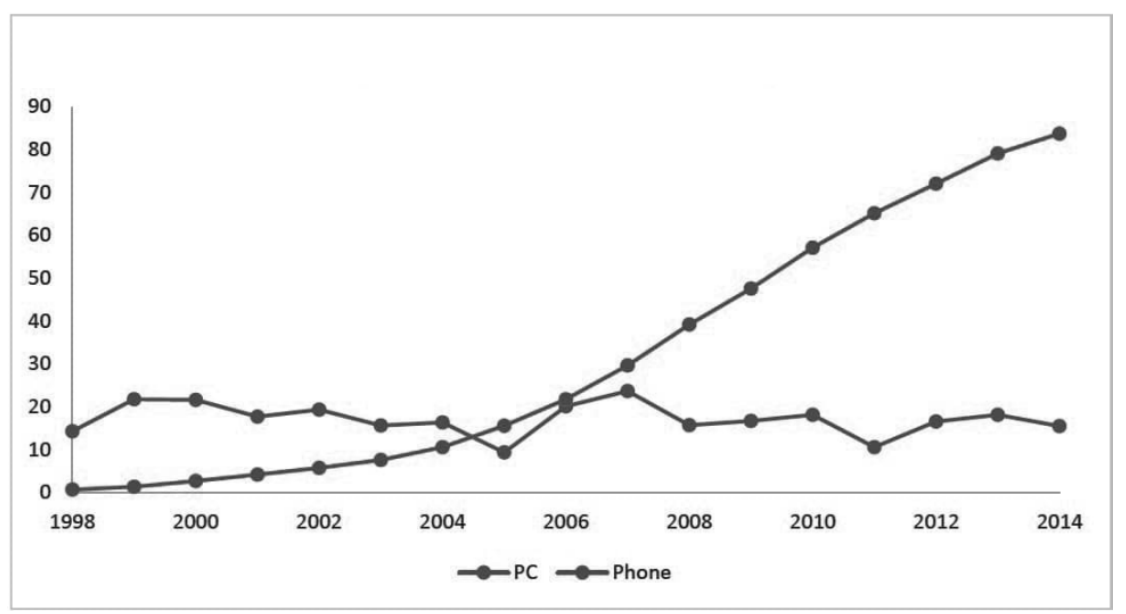

Figure 2. Mean of mobile ownership \& personal computer (1998-2014)

Note . Phone $=$ mobile phone subscribers. $\mathrm{PC}=$ Personal Computers .

On the contrary, the graph for computers does not show increasing or decreasing patterns, it moves along the horizon independently. As the results in Table 3 show, the existence of a negative and statistical significance at one percent correlation between PC and FDI inflow is because of technological advancement. As ICT advances, the technology brings better quality computers, accessories, and software that increase the lifespan of a PC as well while reducing computer's buying frequency, (Marks, 2012; BBC, 2016). The computer's quality and lifetime are being enhanced by improving software and ICT services in Africa, instead of replacing new computers.

\section{Data and Descriptive Statistics}

This paper used panel data from multiple sources, the International Telecommunication Union (ITU), and World Bank. For the measure units of variables, the following were applied; Internet users (per 100 persons), Mobile cellular subscribers (per 100 inhabitants), and Personal Computers (per 1000 people). Internet users were defined as the number of individuals using the internet at any point in time in a particular year. Mobile cellular subscribers were defined as the users of portable telephones subscribing to a public mobile telephone service using cellular technology. Personal computers were treated as self-contained computers designed for use by a 
single individual. Data on Internet users, Mobile, and personal computers were from (ITU). ITU collects data using satellite, orbit, and ICT industries. FDI inflow (per million US dollars) data sourced from World Bank (WDI). The control variables (GDP \& per capita income) come from World Development Indicators.

Table 1 indicates the variables applied in the full sample. Although mean and standard deviations measure different patterns of the data, they are still related and important indicators of data characteristics. The key variable of interest is the internet and the mean is about 5.9 with a standard deviation of 9.6 showing that the mean is smaller than the standard deviation, implying that the data were more spread out.

Table 1. Summary statistics

\begin{tabular}{lccc}
\hline VARIABLE & $\mathrm{N}$ & MEAN & SD \\
\hline Outcome Variable & & & 18.316 \\
Log FDI Inflow & 901 & 7.142 & 9.655 \\
Independent Variable & & & 38.347 \\
Internet Users & 901 & 5.975 & 32.141 \\
Mobile Ownership & 901 & 31.95 & 3412.7 \\
Personal Computers & 714 & 17.07 & 62.14 \\
Control Variables & & & 2043 \\
GDP Per Capita & 901 & 26.43 & \\
GDP (Billion) & 901 & & \\
\hline
\end{tabular}

Note. The internet users and mobile phone ownership are percentages per hundred individuals, while computers are per thousand. The measuring unit for FDI inflow and GDP per capita is per million and per thousand, respectively.

This means the countries in the sample have wide-ranging internet users per hundred populations. This table provides summary statistics of explanatory and outcome variables indicating standard deviations of all variables are greater than their means but no extreme distance between the two. A high rate of standard deviation implies the mean is less representative of data and vice versa.

Table 2 provides the correlations among all variables used in the study. Table 2 in Column 1 indicates the foreign direct investment (FDI) inflow and gross domestic products (GDP) are highly related. In column 2, the internet and mobile ownerships are closely related. The correlations among other variables seem less. The FDI inflow carries its effects on the economy forward to the next years and none of this data is lagged. FDI inflow and GDP are recorded in the same year which means FDI hasn't produced its economic effects yet and it has a close relationship with the market size of the host country.

Table 2. Correlation among variables (Pearson's coefficient)

\begin{tabular}{lcccccc}
\hline & $(1)$ & $(2)$ & $(3)$ & $(4)$ & $(5)$ & $(6)$ \\
\hline 1. Log FDI Inflow & 1.000 & & & & & \\
2. Internet Users & 0.472 & 1.000 & & & & \\
3. Mobile Ownership & 0.374 & 0.73 & 1.000 & & & \\
4. Computers (PC) & $(0.003)$ & 0.29 & 0.20 & 1.000 & & \\
5. Per Capita GDP & 0.118 & 0.25 & 0.24 & 0.25 & 1.000 & 1.000 \\
6. GDP & 0.698 & 0.22 & 0.12 & $(0.033)$ & 0.12 & \\
\hline
\end{tabular}

The GDP has a negative relationship with the PC. FDI and GDP have a high-rate relationship but PC has a negative correlation with GDP and FDI inflow. The percentage rate of PC relationship with GDP and FDI inflow is the same and very small. The bracket sign indicates negative sign, which mean the number inside the parenthesis has negative correlation to respective variable.

The correlations between internet users and mobile phone ownerships are quite high because the internet has effects on mobile phone users in many ways, through direct job creation and indirect job creation via attracting FDI inflow, which will increase local's purchasing powers. Moreover, the increase in internet availability and speed encourages mobile phone ownership because people use it for internet access. Greater technology availability creates a greater technology adaptation in the communities.

\subsection{Empirical Estimation}

To examine whether the increasing ICT infrastructure in Africa has a connection with inward FDI, this paper 
analyzed the relationship between Foreign Direct Investment (FDI) inflow and Information and Communication Technology (ICT) in Africa in a given time (1998-2014). The first part of the study tests the relationship between FDI inflow and the increasing ICT infrastructures in Africa using the Fixed Effect model. After undersea internet cables' arrival to Africa shores from Europe and the Middle East, ICT infrastructures dramatically developed and increased in Africa. And, for endogeneity free results, the second part tests whether the increase in FDI inflow to Africa is higher in the countries with access to the sea or the countries without access to the sea, by applying the natural experiment method.

The key variable is the Internet while the outcome variable is logged FDI inflow to African countries over the period of 17 years. In the experiment, the countries that have access to the shores are treatment and the countries that have no access to the sea are control groups. The study experiments the average changes of FDI inflow in these two areas after and before intervention (2009). The landlocked countries have no chance to have direct submarines internet cables but they depend on the transfers from other countries which have access to the sea/shores.

\section{Research Methodology}

The paper attempts to answer the question of whether there exists a relationship between the increase in ICT infrastructures in Africa and FDI inflow to Africa over the last decades using panel data. The paper used a fixed effect method and difference-in-difference techniques. A fixed-effect model was used because the study employs panel data where FE is the most appropriate model. The paper uses panel data, this model handles fixed effects of country-level factors. The Difference-in-difference model was used for two reasons: 1) for robustness check of the outcome, and 2) to identify the differential effects of submarines internet cable arrival to Africa on FDI inflow in the countries with access to the sea and countries without access to the sea. This quasi-experiment model offers better quality estimates in mitigating any potential bias. The standard errors were clustered at the country level. The basic model specification is as follows:

$$
\text { lnfdi } i_{i t}=\alpha_{0}+\alpha_{1} \text { internet }_{i t}+\alpha_{2} \text { phone }_{i t}+\alpha_{3} P C_{i t}+\alpha_{4} g d p_{i t}+\alpha_{5} i n c_{i t}+\alpha_{6} C_{i}+\alpha_{7} y_{t}+\varepsilon_{i t}
$$

Where $f d i_{i t}$ represents a log of Foreign Direct Investment (FDI) inflow, it is an outcome for a country $i$ and at time $t$. The internet $_{i t}$ stands for internet users per 100 inhabitants in the country $i$ and at period $t$ where internet users refer to the number of people that have used the internet at any point in time during a specific year. $P C_{i t}$ represents personal computers per 1000 inhabitants in the country $i$ at time $t$. The phone $e_{i t}$ denotes mobile cellular subscribers per 100 inhabitants in the country $i$ and mobile cellular subscribers refer to users of portable telephones subscribing to an automatic public mobile telephone service using cellular technology that provides access to the public switched telephone network. The $g d p_{i t}$ is a market size of the host country measured by Gross domestic Products (GDP). The $i n c_{i t}$ is a per capita income of the host country used for destination development. The $\mathrm{C}_{\mathrm{i}}$ and $y_{t}$ are country and year and captures the specific-effect of location and time on FDI inflow, respectively, while $\varepsilon_{i t}$ is error term.

\subsection{Empirical Results}

A high level of ICT infrastructure indicates economic development in both human capital improvement and disposable income where people have discretionary income. ICT infrastructure itself enhances economic and human development through the education system, health, communication, and research and development. Table 3 is a basic model that shows the main outcomes revealing the effects of ICT infrastructure on FDI inflow to Africa. In Africa, the economic contribution of internet accessibility and internet speed are more pronounced in the existing literature. An increase in high-speed internet accessibility brought by submarines internet cables from Europe and elsewhere to Africa promotes innovation, inward foreign investments, and integration of global economy with Africa and eventually makes overall Africa attractive to investment and tourism. Besides, Africa is marked with a fast-growing number of mobile phone technology subscribers across the globe. Avoiding any potential correlation between explanatory variables, each independent variable is once dropped to demonstrate the effects of the key variable (internet).

Using fixed effect techniques, the result shows some slight changes from column 1 to column 4 in table 3 . For column 1, it is a full sample where the effects of many variables are controlled, showing a positive and statistically significant relationship between an increase in ICT infrastructure and FDI inflow to Africa, where a one-unit surge in internet and mobile phone ownership increases the FDI inflow to Africa at 62.6 and 6 percent, respectively. The mean of the FDI inflow and internet users are 7.142 and 5.975, respectively. This average mean is an overall average of FDI and Internet users over 17 years of sample and each year has different mean and standard deviation implying the relationship between FDI and Internet users may vary across the years (for details, see appendix). The inference of a strong and long-held relationship between FDI inflow and Internet 
users can be seen in figure 1 and detailed summary statistics in Appendix.

Table 3. Basic estimation results of FDI inflow to Africa and ICT

\begin{tabular}{|c|c|c|c|c|c|c|c|}
\hline Variables & (1) & (2) & (3) & (4) & $(5)$ & $(6)$ & (7) \\
\hline \multirow[t]{2}{*}{ Internet } & $0.626^{* * *}$ & $0.602 * * *$ & $0.694 * * *$ & $0.679 * * *$ & $0.621 * * *$ & $0.627 * * *$ & $0.622 * * *$ \\
\hline & $(0.0641)$ & $(0.0547)$ & $(0.0592)$ & $(0.0504)$ & $(0.0645)$ & $(0.064)$ & $(0.0644)$ \\
\hline \multirow[t]{2}{*}{ PC } & $-0.0299 *$ & & $-0.0310^{*}$ & & $-0.0329^{*}$ & $-0.0301 *$ & $-0.0337 *$ \\
\hline & $(0.0182)$ & & $(0.0183)$ & & $(0.0183)$ & $(0.0182)$ & $(0.0182)$ \\
\hline \multirow[t]{2}{*}{ Mobile } & $0.0634 * * *$ & $0.0643^{* * *}$ & & & $0.0663^{* * *}$ & $0.0634 * * *$ & $0.0664 * * *$ \\
\hline & $(0.0234)$ & $(0.0183)$ & & & $(0.0235)$ & $(0.0234)$ & $(0.0235)$ \\
\hline \multirow[t]{2}{*}{ Constant } & 1.301 & 0.743 & 1.301 & 0.725 & 2.349 & 1.382 & $2.771 * *$ \\
\hline & (1.461) & (1.143) & (1.468) & (1.15) & (1.43) & (1.423) & (1.366) \\
\hline GDP & yes & yes & yes & yes & & yes & \\
\hline Income & yes & yes & yes & yes & yes & & \\
\hline Country & yes & yes & yes & yes & yes & yes & yes \\
\hline Time & yes & yes & yes & yes & yes & yes & yes \\
\hline $\mathrm{N}$ & 714 & 901 & 714 & 901 & 714 & 714 & 714 \\
\hline R-squared & 0.358 & 0.344 & 0.351 & 0.334 & 0.349 & 0.358 & 0.348 \\
\hline Sample & 53 & 53 & 53 & 53 & 53 & 53 & 53 \\
\hline
\end{tabular}

Note. Column 1, is full sample; in column 2 PC was dropped; and in column 3, Mobile phone is dropped. In column 4, PC and Mobile phone are dropped to show the effects of a key variable (Internet). In columns 5 \& 6 GDP, GDP per capita income are dropped, respectively. In column 7 , both GDP and Per capita are dropped. The changes are negligible throughout the columns. Significance Level, $* * * \mathrm{p}<0.01, * * \mathrm{p}<0.05, * \mathrm{p}<0.1$.

Conversely, personal computers show a negative and statistically significance at ten percent throughout the table. The significance level of personal computers is the lowest level compared to other explanatory variables. There exist a negative and significant correlation between PC and FDI inflow because the computer's quality and lifetime have been enhanced by improving software and IT services in Africa, instead of replacing new computers. As the ICT advances, the technology brings better quality computers, accessories, and software that increase the lifespan of a PC and reduces their buying frequency (Marks, 2012; BBC, 2016). Smart phones and tablets replaced Personal computers. Internet cafes are disappearing so that is causing further diminishing of computers usage, since the internet is available almost everywhere through more flexible and portable devices. Personal computers become less among non-academician internet users and travelers because smartphones are user-friendly and quite more convenient than computers and they can perform better than computers do. Due to increasing security vigilance, it is hard to travel with computers at airports, therefore business people and travelers prefer iPad, galaxy, and smart phones.

Before 2006 in Africa, most people visited and used internet cafes for internet connectivity and there was no mobile internet package or internet access with mobile phones. Now, it's so common to see all members of a family having smart phones and a few computers or no even one single computer. Internet usage trends brought trends in PC and smart phone use. Further, mobile banking and fast speed internet availability make Africa have the fastest-growing market of Mobile technology. Hence, as FDI inflow to Africa increases, as facilitated by the ICT infrastructures, and it consequently increases economic growth. This economic growth enhances mobile phone ownership and internet access through job creation and promoting local purchasing-power and adapting the technology. Computers are only used in office and large data file users or researchers while the use of the internet and mobile phone ownership becomes part of basic things.

\subsection{Endogeneity Treatment}

Although there is plenty of research on correlations between ICT and FDI inflow in different countries and regions in existing literature, there would be a possible endogeneity problem. ICT infrastructure and FDI inflow increase in Africa may have a causality problem since fiber optic submarine cables from outside Africa itself can be part of FDI inflow to Africa. In other words, FDI inflow itself can be a driven factor in the development of ICT infrastructure in Africa. Therefore, the study examined internet effects on FDI inflow in the location with and without access to the seashores on FDI inflow. Early in 2009, local African companies started bringing more undersea internet cables from the Middle East and Europe to their home countries that improved internet capacities and availabilities in Africa. Thus, the researchers classified Africa as a location with access and without access to the sea, where location with access to the sea is treatment, and the location without access to 
the sea is the control group.

To tackle this issue, the researchers are often interested in a particular effect of the intervention (policy change) in the economy to overcome any potential selection bias that creates an endogeneity problem for the inference. Quasi-experiments (difference in difference) can offer better quality estimates in mitigating these biases. The idea of using the difference-in-difference method is to deal with many different factors that may cause an endogeneity problem. The following model is used to compare Foreign Direct Investment (FDI) inflow to Africa before and after undersea internet cable (Fiber Optic) arrival to Africa.

To identify the differential effects of submarines internet cable arrival to Africa on FDI inflow in the countries with access to the sea and countries without access to the sea before and after submarine internet cables arrival in Africa: the locations were classified landlocked and area with access to the sea. The treatment and control groups are locations with sea access and locations without access to the sea, respectively. As Figure 3 shown, the patterns of treated and controlled areas were almost identical before the submarine cables arrival in 2009, the policy year. In other words, common trend assumption is satisfied in this research environment. After 2009, the treatment variable shows a jump up while the control group sustained its long-continued slight growth without jumps. In 2009, more submarine internet cables started arriving in Africa, which the researcher hypothesized that it increased the FDI inflow to Africa, specifically in the locations with access to the sea. Confirming the hypothesis, the mean of FDI inflow to the countries along the coastline has increased after 2009 more than the countries with no access to the sea. The increasing gap in the FDI inflow between the locations with sea access and the landlocked area started increasing soon after undersea cables arrival to Africa and extends further over years.

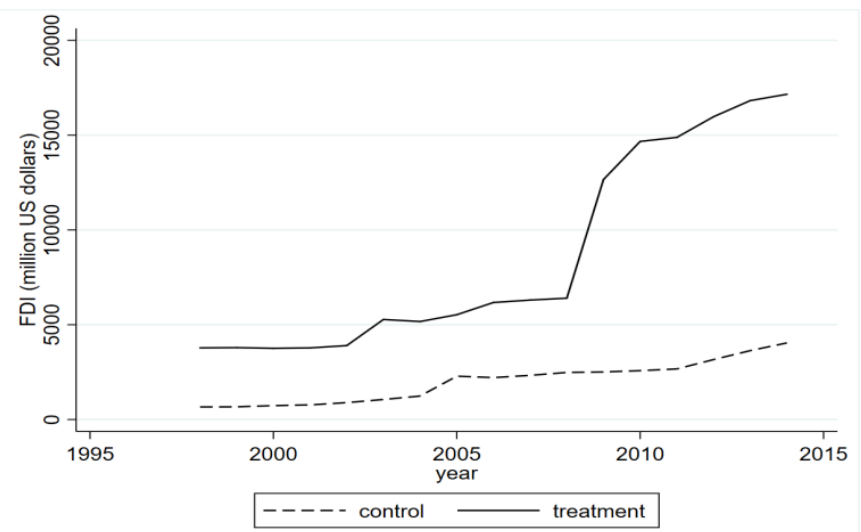

Figure 3. FDI Inflow to the Location without Sea and Locations with Sea in Africa Before and After Submarine Internet Cables Arrival in 2009

Source: Author's computation.

\section{Difference-in-Difference Model}

$$
\text { lnfdi }_{i t}=\beta_{0}+\beta_{1} \text { coastline }_{i}+\beta_{2} y d_{t}+\beta_{3} \text { coastline }_{i} * y d_{t}+\beta_{4} \text { controls }_{i t}+\varepsilon_{i t}
$$

Where $\operatorname{lnfdi} i_{i t}$ is a log of FDI inflow to Africa and coastline $e_{i}$ is a dummy variable that equals one if country $i$ has access to the sea and zero otherwise, assuming that a country with the sea access has submarines internet cables at time $t$. The study considers whether the country has undersea cables or has a chance to have it rather than whether the country $i$ currently has submarine cable or not at time $t$. Even though the researcher doesn't know whether landlocked countries enjoy with fast speed internet or suffer from poor connectivity internet capacity due to distance, the study assumes that landlocked countries never have chance to get direct submarine internet cables, and thus, their internet connection speed is poorer than the countries with sea access. This chapter also does not consider the connectivity capacity of far distance area from the seashore in the country with sea access. The study does this because the focal interest of the study is not only internet speed but also the country's accessibility to a coastline that affects economic development and overall country's attractiveness to FDI inflow, ceteris paribus. Therefore, submarine's internet cables' presence in Africa brings more advantages to the country with the coastline than the landlocked nation.

The $y d_{t}$ is a set of year dummy variable equaling one if it's in post-policy period and zero otherwise. The coastline $_{i} * y d_{t}$ is an interaction term and captures the difference in the differences between the control and treatment group before and after (2009) fiber optic cables arrival to Africa. controls $s_{i t}$ are variables that 
represent for GDP, Per capita income, host country, time, and interactions that capture specific-country and time effects, respectively. The $\varepsilon_{i t}$ is standard error term. The standard errors clustered at the country level.

Table 4. Difference in differences estimation results

\begin{tabular}{lcccc}
\hline Variables & $(1)$ & $(2)$ & $(3)$ & $(4)$ \\
\hline diff-in-diff & $7.462 * * *$ & $7.060^{* * *}$ & $7.953^{* * *}$ & $7.519 * * *$ \\
& $(2.692)$ & $(2.611)$ & $(2.919)$ & $(2.824)$ \\
Log of GDP & yes & yes & \\
Income & yes & yes & yes & yes \\
Country & yes & yes & yes & yes \\
Time & yes & yes & yes & yes \\
Interactions & yes & yes & 901 & 901 \\
Observations & 901 & 901 & 0.624 & 0.207 \\
R-squared & 0.625 & 0.215 & -1.281 & 2.082 \\
Constant & -1.481 & 1.505 & $(2.13)$ & $(1.68)$ \\
& $(2.22)$ & $(2.08)$ & 53 & 53 \\
Countries & 53 & 53 & & \\
\hline
\end{tabular}

Note. For column 1, it is a full sample controlling GDP, Per Capita, destination, time, and interaction fixed effects. For column 2, the GDP and column 3 income per capita was dropped, respectively. For column 4, both the GDP and per capita were dropped at the same time. Interestingly, GDP is the most influencing control variable on the outcome. The standard errors clustered at the country level. Significance Level, $* * * p<0.01$, $* * \mathrm{p}<0.05, * \mathrm{p}<0.1$

According to table 4, the results indicate that the submarine's internet cable arrival to Africa itself increases FDI inflow to Africa. This means, FDI inflow to Africa has increased after 2009 (the time more fiber optic internet cables started arriving in countries on the coast) and that increase is considerably higher in the countries with sea access than countries without sea access. For simplicity, average changes of FDI inflow to countries with the coastline in Africa after 2009 are greater than that of the landlocked countries. The increase and advancement of ICT infrastructures promote economic development and social integration through improving productivity growth, education, and research and development. Although this Quasi-experimental method is known for a quality estimation result, there may be other factors that trend in between two interval times which might be responsible for the changes apart from fiber optic internet arrival to Africa.

\section{Conclusion and Policy Implication}

This paper investigated the relationship between FDI inflow to Africa and increasing ICT infrastructures in Africa. Since the beginning of the $21^{\text {st }}$ century, ICT infrastructures have been increasing in Africa enhancing communication and mobile phone ownership, and at the same time, FDI inflow to Africa has dramatically increased after submarines internet cables arrival to the shores of Africa. Therefore, this paper is intended to analyze the relationship between FDI inflow and ICT infrastructures in Africa using country-level panel data spanning 17 years (1998-2014) in 53 African countries applying fixed effects and difference-in-differences techniques.

The study also addresses some endogeneity bias that might be initiated from the relationship between FDI and ICT. The FDI inflow may invest in the ICT industry, so the ICT infrastructures could be part of FDI inflow to Africa that might cause a reverse causality. To deal with endogeneity bias, African countries were grouped as control and treatment group where landlocked countries are the controls and countries with sea access are the treatment group, using natural experiment techniques. In this regard, the analysis does not consider the internet speed and connectivity capacity between landlocked and non-landlocked countries due to distance and second-transfer, it just counts whether the country has a chance to have direct submarine internet cables or not. The central point of interest is about the country's accessibility to the sea to receive a first-hand fiber optic internet, which improves the location advantages and overall country's attractiveness to FDI inflow, ceteris paribus.

Then, the robust results show that Information \& Communication Technology has a positive and significant relationship with FDI inflow to Africa. The researcher documented that the increase in ICT infrastructure results in increases in FDI inflow to Africa. For simplicity, the increase of ICT in Africa has substantially increased the FDI inflow to Africa, specifically in countries with access to the coastline than in landlocked countries after 
2009. In other words, the average change of FDI inflow to landlocked countries in Africa after 2009 is smaller than that of the countries with the coastline. After comparing the average change of FDI inflows in landlocked countries with that in countries with sea access, after and before 2009; this chapter concludes that ICT can attract more FDI flows for the countries with access to seashores than the countries without access to the sea, ceteris paribus.

The outcomes reveal a good implication for the importance of ICT infrastructure to economic development in Africa. As the result shows, when all other things remain equal, ICT attracts more FDI inflow to countries with sea access than landlocked countries in Africa. The result implies that FDI goes to countries with access to the sea comparing to countries without access to the seashores. ICT infrastructure improvement is also more pronounced in the countries that have sea access where blue economy and ICT combined make their locations more attractive. A high level of ICT infrastructure indicates economic development in both human capital improvement and disposable income where people have discretionary income. ICT infrastructure itself enhances economic and human development through the education system, health, communication, and research and development. This is true because countries alongside the coastline get firsthand submarine internet while landlocked countries depend on the transfer of other countries. This finding does confirm the argument that: "the landlocked countries are economically constrained not only by the lack of blue economy (traditional economy) but also have effects on other overall prospective development activities". After the arrival of undersea internet cables to Africa, the sea becomes very critical for economic development more than ever before, contributing to other potential developments rather than just the traditional blue economy. It implies that having a coastline means more to a country's development than just the blue economy.

Landlocked countries should improve policy-related issues to enhance their FDI inflow position, which may include trade policy, tax, human skills, good governance, and quality of economic institutions. The improvement of the above elements would make landlocked countries favorable business environments attracting more FDI inflows. The landlocked country's collaboration neighbors in the development of infrastructure and ports would also improve the accessibility of seawater. On the other hand, countries with access to the sea should improve their seaport facilities and deepen their knowledge of the ocean to achieve optimal use of the sea. They also should provide more and good seaport facilities to landlocked countries and passing international sea vehicles ensuring the safety and accessibility of the exclusive economic zone and surrounding international water.

\section{Acknowledgements}

This paper was financially supported by the Chinese Scholarship Council (CSC), Somali National University, and Mr. Abukar Salad Warsame.

Last but not least, I would like to extend my sincere gratitude to Prof. Zhang Jipeng for the continuous guidance and invaluable research-related support during the writing. Highly appreciated your support and services. I am grateful to you all!

\section{References}

Addison, T., \& Heshmati, A. (2003). The New Global Determinants of FDI Flows to Developing Countries. The Importance of ICT and Democratization. UNU/WIDER. Discussion Paper No. 2003/45. https://doi.org/10.1016/S1567-7915(04)04007-8

Alan, A., \& Estrin, S. (2004). The determinants of foreign direct investment into European transition economies. Journal of Comparative Economics, 32(4), 775-787. https://doi.org/10.1016/j.jce.2004.08.006

Assunçao, S., Forte, R., \& Teixeira, A.C. (2011). Location Determinants Of FDI: A Literature Review. FEP Working Papers, 433.

Belkhodja, O. (2016). FDI Location Decision: Evidence from Firms Investing in China. International Journal of Business and Management, 11(6). https://doi.org/10.5539/ijbm.v11n6p47

Blance-Brude, F. et al. (2017). Data Collection for Infrastructure Investment Benchmarking: Objectives, Reality Check and Reporting Framework.

Blomstrom, M., \& Lipsey, R. E. (1991). Firm size and foreign operations of multinationals. Scandinavian Journal of Economics, 93(1), 101-107. https://doi.org/10.2307/3440424

Braunerhjelm, P., \& Svensson, R. (1996). Host country characteristics and agglomeration in foreign direct investment. Applied Economics, 28(7), 833-840. https://doi.org/10.1080/000368496328272

Buckley, P. J., Clegg, L. J., Cross, A. R., Liu, X., Voss, H., \& Zheng, P. (2007). The determinants of Chinese outward foreign direct investment. Journal of International Business Studies, 38, 499-518. 
https://doi.org/10.1057/palgrave.jibs.8400277

Chanegriha, M., Stewart, Ch., \& Tsoukis, Ch. (2016). Identifying the robust economic, geographical and political determinants of FDI: An Extreme Bounds Analysis. Empir. Econ., 52, 759-776. https://doi.org/10.1007/s00181-016-1097-1

Deng, P. (2004). Outward investment by Chinese MNCs: motivations and implications. Business Horizons, 47(3), 8-16. https://doi.org/10.1016/S0007-6813(04)00023-0

Du, J., Lu, Y., \& Tao, Zh. (2007). FDI Location Choice in China: Agglomeration vs. Institutions. International Journal of Finance \& Economics, 13(1), 92-107. https://doi.org/10.1002/ijfe.348

Dunning, J. (1973). The Determinants of International Production. Oxford Economic Papers, 25(3), 289-336. https://doi.org/10.1093/oxfordjournals.oep.a041261

Faeth, I. (2009). Determinants of Foreign Direct Investment - A Tale of Nine Theoretical Models. https://doi.org/10.1111/j.1467-6419.2008.00560.x

Fakher, A. (2016). The Impact of Investment in ICT Sector on Foreign Direct Investment: Applied Study on Egypt. Rev. Integr. Bus. Econ. Res., 5(2).

Siniša, H., Ivan, C., \& Ivan, J. (2019). Determinants of mobile phone ownership in Nigeria. Telecommunications Policy, 43, 101812. https://doi.org/10.1016/j.telpol.2019.03.001

Gholami, R., Tom, L., \& Heshmati, A. (2005). The Causal Relationship between ICT and FDI. Research Paper No. 2005/26. UNU-WIDER 2005.

GSM Association (GSMA). (2017). The mobile economy - sub-Saharan Africa 2017. Retrieved from https://www.gsma.com/subsaharanafrica/wp-content/uploads/2018/11/2017-07-11-7bf3592e6d750144e58d 9dcfac6adfab.pdf

Gupta, R., \& Jain, K. (2015). Adoption behavior of rural India for mobile telephony: A multigroup study. Telecommunications Policy, 39(8), 691-704. https://doi.org/10.1016/j.telpol.2015.01.001

Hjort, J., \& Poulsen, J. (2019). The Arrival of Fast Internet and Employment in Africa. American Economic Review, 109(3), 1032-1079. https://doi.org/10.1257/aer.20161385

Javorcik, B. S. (2004). The composition of foreign direct investment and protection of intellectual property rights: Evidence from transition economies. European Economics Review, 48, 39-62. https://doi.org/10.1016/S0014-2921(02)00257-X

Josep, M., Maite, A., \& Vicente, O. (2015). Location choice of Spanish multinational firms in developing and transition economies. Journal of Business Economics and Management, 18(2), 319-339. https://doi.org/10.3846/16111699.2015.1013980

Kang, Y. (2018). Regulatory institutions, natural resource endowment and location choice of emerging-market FDI: A dynamic panel data analysis. Journal of Multinational Financial Management, 45, 1-14. https://doi.org/10.1016/j.mulfin.2018.04.003

Kang, Y., \& Jiang, F. (2010). FDI Location Choice of Chinese Multinationals in East and Southeast Asia: Traditional Economic Factors and Institutional Perspective.

Kraemer, K, \& Dedrick, J. (1994). Payoffs from investment in information technology: Lessons from the Asia-Pacific region. World Development, 22(12). https://doi.org/10.1016/0305-750X(94)90183-X

Kabir, M. H. (2003). FDI, Information Technology and Economic Growth in the MENA Region.

Markusen, J., \& Venables, A. (1999). Foreign Direct Investment as a Catalyst for Industrial Development. European Economic Review, 43, 335-356. https://doi.org/10.1016/S0014-2921(98)00048-8

Mottaleb, K. A. (2007). Determinants of Foreign Direct Investment and Its Impact on Economic Growth in Developing Countries. Munich Personal RePEc Archive.

Na, Lv., \& Lightfoot, W. S. (2006). Determinants of foreign direct investment at the regional level in China. Journal of Technology Management in China, 1(3), 262-278. https://doi.org/10.1108/17468770610704930

Nishijima, M., Ivanauskas, T. M., \& Sarti, F. M. (2017). Evolution and determinants of digital divide in Brazil (2005-2013). Telecommunications Policy, 41(1), 12-24. https://doi.org/10.1016/j.telpol.2016.10.004

Okafora, G., Piesseb, J., \& Webster, A. (2015). The motives for inward FDI into Sub-Saharan African countries. 
Journal of Policy Modeling, 37, 875-890. https://doi.org/10.1016/j.jpolmod.2015.07.003

Organization for Economic Cooperation and Development (OECD). (2018). Glossary of statistical terms.

Rjoub, H. et al. (2017). Financial Reforms and Determinants of FDI: Evidence from Landlocked Countries in Sub-Saharan Africa. https://doi.org/10.3390/economies5010001

Romanschii, A. (2016). The Impact of Information Communication Technology on Foreign Direct Investment.

Sridhar, S. K., \& Wan, G. (2010). Firm Location Choice in Cities: Evidence from China and India. China Economic Review. https://doi.org/10.1016/j.chieco.2009.11.003

The Economist. (2017). In much of sub-Saharan Africa, mobile phones are more common than access to electricity.

The Economist 1843. (2012). What's the Greatest Invention of All Time?

Veeramacheneni, B., Vogel, R., \& Ekanayake, E. M. (2006). Information Technology, FDI And Economic Growth: An India Case Study. Southwestern Economic Review.

Veljanoska, F., Axhiu, M., \& Husejni, M. (2013). Information Communication Technology as a Determinant of the FDI Flows. Mediterranean Journal of Social Sciences. https://doi.org/10.5901/mjss

Waverman, L., Meschi, M., \& Fuss, M. (2005). The impact of telecoms on economic growth in developing markets. The Vodafone Policy Paper Series, (2).

Yao, S. et al. (2016). Dynamic relationship between China's inward and outward foreign direct investments. China Economic Review, 40. https://doi.org/10.1016/j.chieco.2016.05.005

Zhang, X. (2017). Exploring the patterns and determinants of the global mobile divide. Telematics and Informatics, 34(1), 438-449. https://doi.org/10.1016/j.tele.2016.06.010

\section{Appendix}

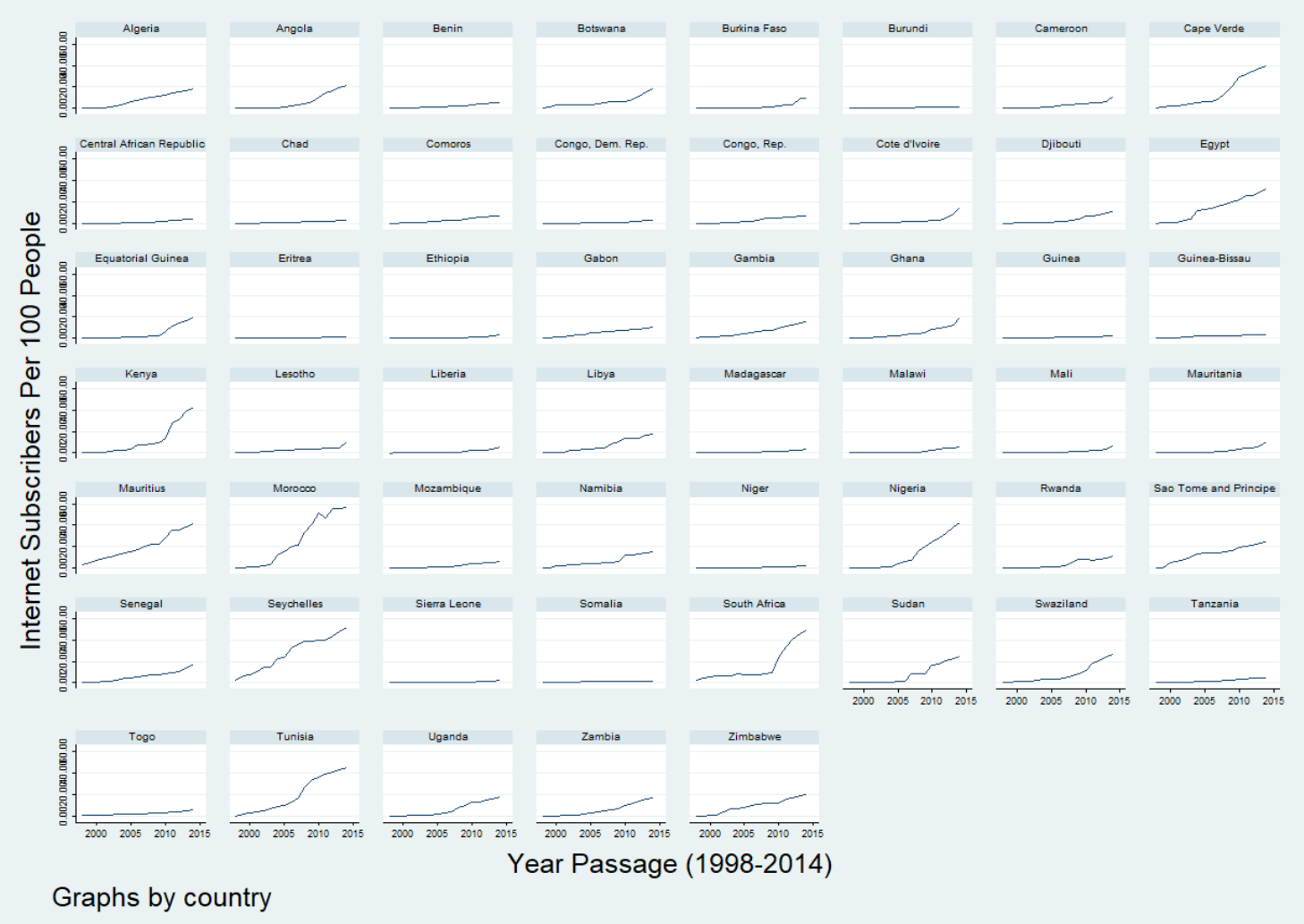

Figure 1. The internet growth in African countries over time (1998-2014)

Source: author's computation. 


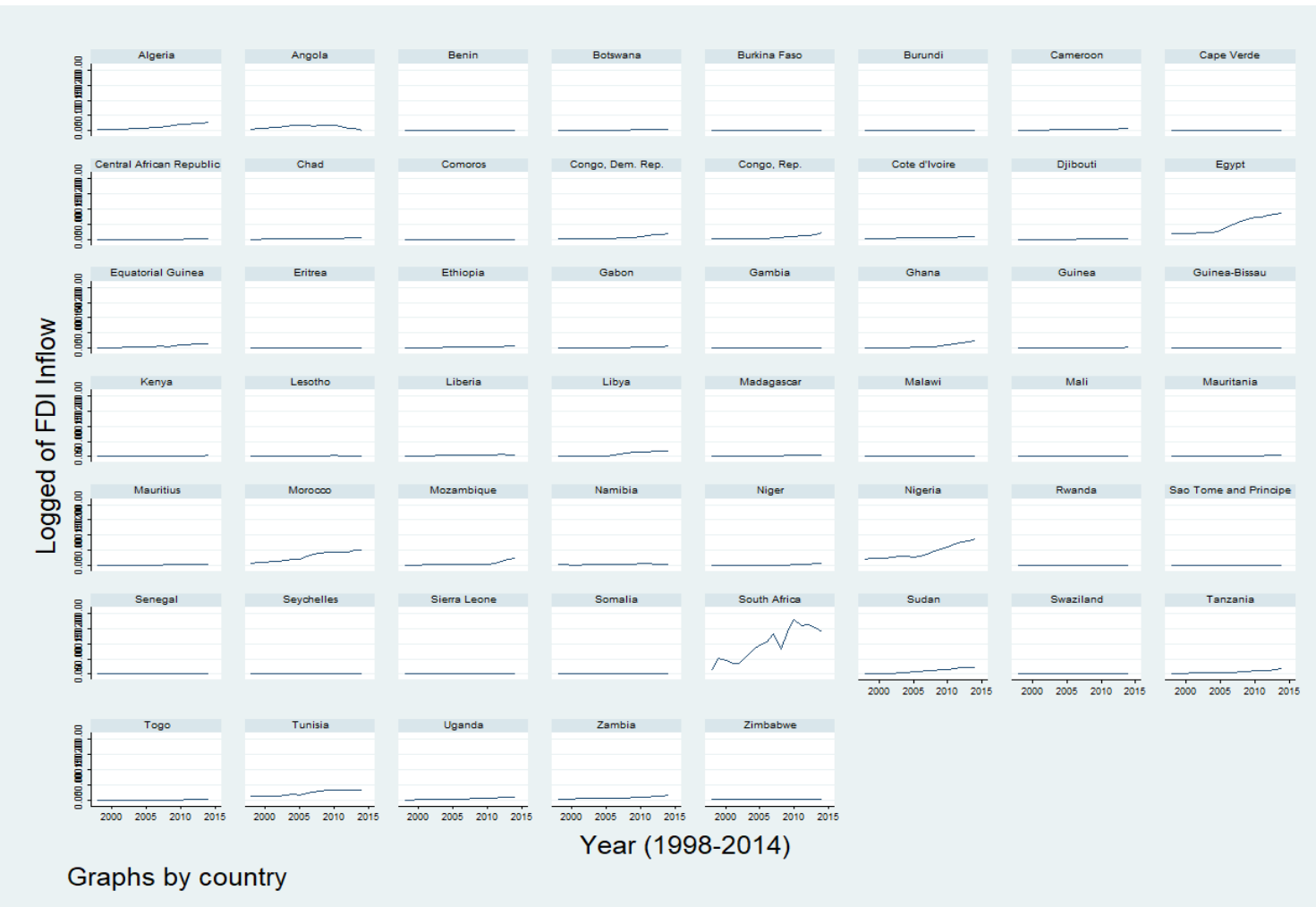

Figure 2. The inward FDI growth in African countries over time (1998-2014)

Note. the FDI inflow to Africa is logged.

Source: author's computation.

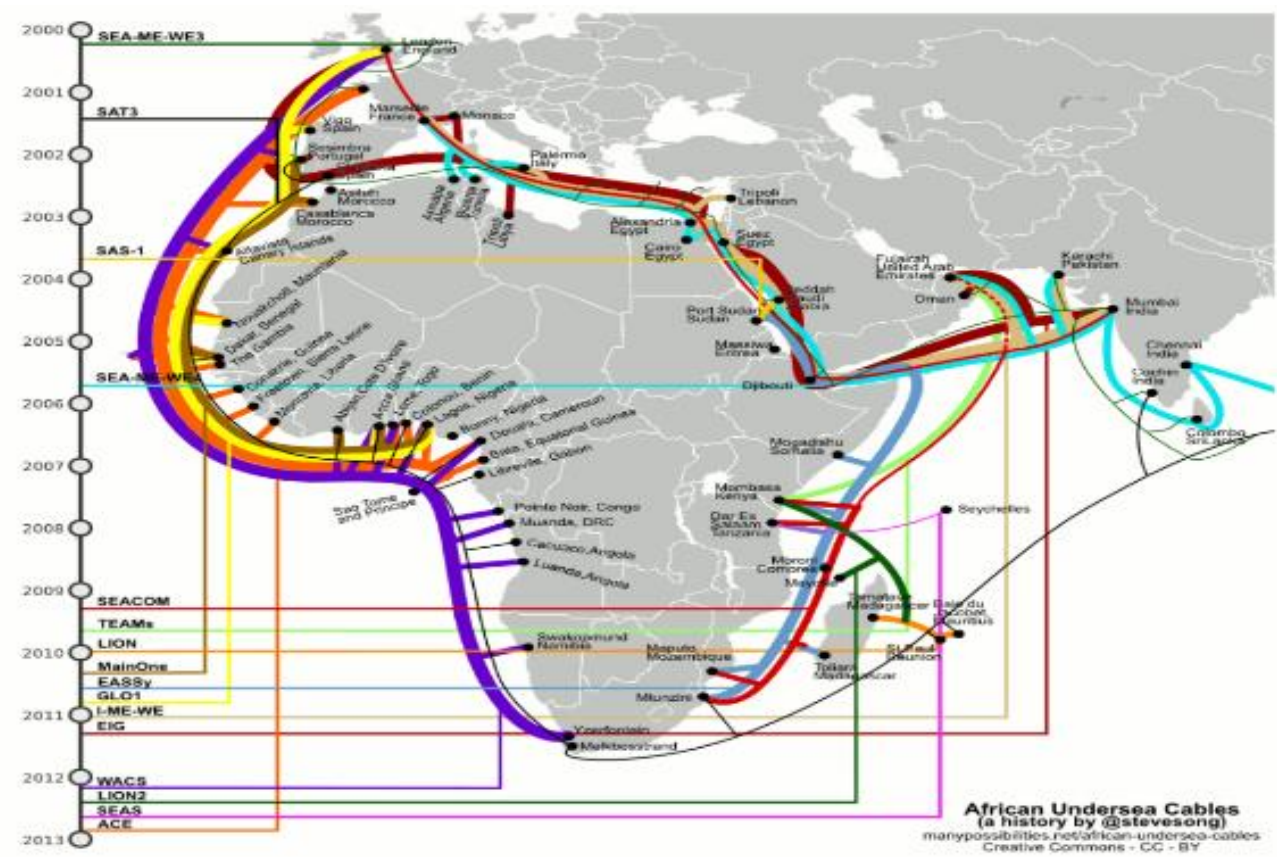

Figure 3. Map of Africa showing undersea internet arrival over time

Source: African Undersea Cables. 
Table 1. Interaction estimation results

\begin{tabular}{lcccc}
\hline Variables & $(1)$ & $(2)$ & $(3)$ & $(4)$ \\
\hline internet*Phone & $0.00601^{* * *}$ & $0.00607^{* * *}$ & $0.00602^{* * *}$ & $0.00609^{* * *}$ \\
& $(0.000474)$ & $(0.00048)$ & $(0.000473)$ & $(0.00047)$ \\
internet*PC & $-0.00334^{* * *}$ & $-0.00334^{* * *}$ & $-0.00335^{* * *}$ & $-0.00337^{* * *}$ \\
& $(0.000623)$ & $(0.00063)$ & $(0.000621)$ & $(0.00063)$ \\
GDP & yes & & yes & \\
Per capita income & yes & yes & yes & yes \\
Countries & yes & yes & yes & yes \\
Time & yes & yes & 714 & 714 \\
Observations & 714 & 714 & 0.365 & 0.358 \\
R-squared & 0.365 & 0.358 & 1.396 & $2.529 *$ \\
Constant & 1.368 & 2.228 & $(1.385)$ & $(1.33)$ \\
\end{tabular}

Note. The internet*Phone and internet*PC represent the interaction between the internet and mobile phone ownership, and interactions between the internet and personal computers, respectively.

Significance level: *** $\mathrm{p}<0.01,{ }^{* *} \mathrm{p}<0.05, * \mathrm{p}<0.1$.

Table 2. Definitions of variables

\begin{tabular}{ll}
\hline VARIABLES & DEFINITION \\
\hline Outcome & Per million Us dollars \\
Log FDI Inflow & \\
Independents & Internet users per 100 inhabitants \\
Internet Users & Mobile cellular subscribers per 100 inhabitants \\
Mobile Phone & Personal Computers per 1000 inhabitants \\
Personal Computers & \\
Controls & Log of Gross Domestic Product (per billion US dollars) \\
GDP & Per thousand US dollars \\
Per Capita Income & \\
\hline
\end{tabular}

\section{Copyrights}

Copyright for this article is retained by the author(s), with first publication rights granted to the journal.

This is an open-access article distributed under the terms and conditions of the Creative Commons Attribution license (http://creativecommons.org/licenses/by/4.0/). 